4. Cini, M., \& Borragan, N. P.-S. (2016). European Union Politics (5th ed.). Oxford: Oxford University Press.

5. Dinan, D. (2004). Europe Recast: A history of European Union. London: Palgrave Macmillan.

6. Richardson, J. (2001). European Union: power \& policy-making (2nd ed.). New York: Routledge.

7. Korbut, D. (ed.) (2001). Jevropejsjka integhracija: krok za krokom: posibnyk dlja zhurnalistiv [European Integration: Step by Step: A Guide for Journalists]. Kyiv: Europe XXI Foundation. (in Ukrainian)

8. Roy, J., \& Kanner, A. (2006). Historical Dictionary of the European Union (Historical Dictionaries of International Organizations Series). Lanham: Scarecrow Press.

\title{
DEVELOPMENT OF A COMPETITIVE ENVIRONMENT IN THE NATIONAL ECONOMY
}

\section{Yuliya Yasko ${ }^{1}$}

DOI: https://doi.org/10.30525/978-9934-588-39-6-51

An indispensable condition for the effective functioning of the national economy is the development of a competitive environment - as a result and a combination of conditions of interaction of all market agents. The competitive environment is a set of socio-economic, organizational, legal, institutional and other conditions and factors that influence the development and level of competition for the most favorable conditions of activity in the relevant market. A competitive environment is a complex and multidimensional system of relationships that has such characteristics as integrity, interaction and interdependence and hierarchical structure. The peculiarity of the competitive environment is that it contains information not only on the level of competition, but also the degree of completeness of the market and market conjuncture. This is the difference between the competition and the competitive environment. The competitive environment for economic agents serves as an externally conditioned commodity market. The competitive environment is the result of the action of the entire population of economic entities, including the state [1, p. 23].

The development of a competitive environment occurs through direct and indirect state intervention in economic and market processes through the implementation of pro-competitive intra-sectoral regulation and direct state

\footnotetext{
${ }^{1}$ Kyiv National University of Trade and Economics, Ukraine
} 
intervention through the opening of new markets and the elimination of anticompetitive sectoral regulation. European experience shows that the national economy is thriving if the proportion of large companies that realize economies of scale is combined with a large proportion of medium and small firms that are flexible in introducing new ideas and opportunities [2, p. 51-73]. Today we can observe the pattern that the production of large capital-intensive production is inefficient. On the contrary, the economy is getting a new «breath» based on the development of the market for modern innovative hightech products, which basically does not require the use of capital-intensive technologies. The interconnection of breakthrough innovation and market efficiency is an important and necessary condition for the development of modern economic systems [3].

A key task that substantiates the need to create an effective competitive environment in the national economy is to evaluate its effectiveness. An effective competitive environment in its content must be adequate to the existing conditions of economic development of society. To achieve this, it is necessary to create a system of performance indicators for the competitive environment.

Indicators of development of effective competitive environment in commodity markets, in our opinion, include: dynamics of volumes of goods sold in markets with competitive structure and in markets where structural prerequisites for competition are absent; dynamics of concentration level indicators in strategic industries; the dynamics of the number of entities entering the commodity markets.

It should be noted that in the modern economy of Ukraine it is quite difficult to estimate the real state of development of competitive environment. In particular, this is due to the inequality of institutional and economic opportunities for all economic entities, the presence of asymmetry that has now emerged in representing the interests of different entrepreneurs in public authorities, and the expansion of lobbying of one another at the expense of others. In addition, in the presence of a significant shadow sector, official statistical information is not always reliable. There is virtually no necessary statistical information on the levels of competition in the markets for goods and services and the factors that affect these levels.

It should be noted that the competitive environment can be effective when it is oriented in two directions: to the foreign market - by assisting domestic entrepreneurs in their high-tech exports, and to the domestic market by improving the competitiveness of domestic products with respect to imported ones.

Increasing the efficiency of the competitive environment implies a significant increase in the role and responsibility of public authorities for the development of competition in commodity markets. The relevant state 
institutions should ensure effective management of the development of these markets through effective legal and regulatory support, improving the distribution of powers and functions between different public authorities.

At the state level, priority areas and measures for improving the competitive environment are defined in the Draft Concept of the State Policy for Development and Protection of Economic Competition in Ukraine [4]. These include:

- collecting, processing, analyzing the use of data on markets and entities, monitoring markets, relevant analysis of the competitive environment and policies;

- removing barriers to market access, preventing the creation of new barriers; stimulating entry into existing markets of new entrants;

- preventing obstacles to the creation of new markets, facilitating the creation of a competitive environment in emerging markets;

- creating quality infrastructure and providing market participants with access to it.

In our opinion, in determining the effectiveness of the competitive environment, it is important to evaluate the effectiveness of the activities of the antitrust authorities directly involved in this field.

There are a number of essential features that are inherent in effective competition authorities, such as independence, transparency and accountability; guarantees of implementation of certain decision-making procedures; a sufficient financial base commensurate with the institution's mission. In addition, the presence of highly educated, qualified, honest and incorruptible employees is an important element of efficiency. Effective mechanisms of internal and external evaluation of the work of the agency also play an important role in organizing the effective work of competing agencies. At the same time, it is extremely important for the improvement of the work of the department that the purpose and priorities in its work are properly defined, the proper allocation of resources and the making of effective decisions.

The effectiveness of the activities of antitrust agencies is determined by International Independent Organizations and Publications. Thus, the Global Competition Review (GCR), an independent international publication, annually compiles an international rating for the performance of competing agencies [5].

The Global Competition Review is one of the most respected experts in the field. It is formed on the basis of independent expert evaluation of representatives of the foreign legal and business community, in accordance with the criteria developed by these publications. 
The methodology for calculating places in this rating is as follows: activity is rated on a 5-point scale, broken down by departments by the number of points (stars) into groups: elite, very good, good, satisfactory. A thorough examination of the findings contained therein allows us to identify the strengths and weaknesses of the agency's activities and to identify ways to improve competition law and law enforcement. The evaluation criteria in this publication are predominantly internal: effectiveness of investigations, lawmaking, staff qualifications, openness, etc.

GCR analyzes foreign antitrust authorities annually for 18 years. Unfortunately, in 2019 (as in previous years) Ukraine did not enter this international GCR rating. The first place in this rating has taken the European Commission. Also in the elite group of leaders are the departments of France, Germany, the United Kingdom, two US agencies: the antitrust unit of the US Department of Justice and the US Federal Trade Commission [5].

Thus, one of the defining conditions for the development of competition in commodity markets is the state of the competitive environment. Effective competition between economic entities is a necessary prerequisite for sustainable economic development and its successful functioning, an incentive for innovation and the guarantee of social well-being.

\section{References:}

1. Lahutin, V. (2016). Competitive policy of the state: mechanism of realization. Visnyk Kyivs'koho natsional'noho torhovel'no-ekonomichnoho universytetu, vol. 4, pp. 22-37.

2. Albiol-Sanchez J., van Stel A. (2016). Investigating the impact of small versus large firms on economic performance of countriesand industries. In: D. Bogenhold, J. Bonnet, M. Dejardin, D.G. Perez de Lema (eds.). Contemporary entrepreneurship: Multidisciplinary perspectives on innovation and growth. Switzerland: Springer International Publishin.

4. Draft Concept of State Policy for Development and Protection of Economic Competition in Ukraine. URL: http://www.amc.gov.ua/amku/doccatalog/document? id $=146848 \&$ schema $=$ main

5. Global Competition Review. URL: http://www.globalcompetitionreview.com 